\title{
Exocrine pancreatic secretions in growing pigs fed diets containing different levels of protein from soyabean meal
}

\author{
S. Li, W. C. Sauer', S. X. Huang and V. M. Gabert \\ Department of Agricultural, Food and Nutritional Science, \\ University of Alberta \\ Edmonton, T6G 2P5, Canada
}

(Received 9 April 1997; accepted 15 May 1997)

\begin{abstract}
Six barrows, average initial BW $20.2 \pm 0.9 \mathrm{~kg}$, were fitted with a pancreatic pouch re-entrant cannula. Following a 14-d recuperation period, the pigs were fed two diets according to a crossover design, twice daily. Two maize starch-based diets were formulated to contain 12 and $24 \%$ CP from soyabean meal. The experiment consisted of 2 periods of $12 \mathrm{~d}$ cach. The average BW at the start of periods 1 and 2 were $24.0 \pm 1.1$ and $31.3 \pm 2.6 \mathrm{~kg}$, respectively. The average BW at the conclusion of the cxpcriment was $40.2 \pm 1.6 \mathrm{~kg}$. The daily volume of secretion was slightly higher $(\mathrm{P}<0.05)$ in pigs fed the low compared with the high protein diet. There were no differences $(P>0.05)$ in total protein output in pancreatic juice although the protcin concentration $\left(\mathrm{g} / \mathrm{I}^{-1}\right)$ was higher $(\mathrm{P}<0.05)$ in pigs led the high protein diet. There was no effect $(\mathrm{P}>0.05)$ of dictary $\mathrm{CP}$ level of the total activities (units $24 \mathrm{~h}^{-1}$ ) of chymotrypsin, trypsin, amylase and lipase. The specific activities (units $\mathrm{l}^{-1}$ ) of chymotrypsin and amylase were higher $(\mathrm{P}<0.05)$ when the high protein diet was fed. An increase in $\mathrm{BW}$ augmented $(\mathrm{P}<0.05)$ the secretion of volume of pancreatic juice, protein output and total activities of chymotrypsin and lipase. In conclusion, there were no differences in total protein output and total enzyme activities in pancreatic juice when the dietary CP content ranges from 12 to $24 \%$.
\end{abstract}

KEY WORDS: pigs, protein, pancreatic secretions, enzyme activitics

\section{INTRODUCTION}

There is a scarcity of information on the effect of dielary CP levels on the total secretion of protein and enzyme activities in exocrine pancreatic secretions. Hee et al. (1988), in studies with pigs fed a maize starch-based diet containing $15 \% \mathrm{CP}$ 
from soyabean meal or a maize starch-based protein-free diet, reported no differences $(P>0.05)$ in the total secretion of protein and total lipase activity. However, the total activities of trypsin, chymotrypsin and amylase were considerably lower $(\mathrm{P}<0.05)$ in pigs fed the protein-free diet. In another study, Corring and Saucier (1972) fed growing pigs four maize starch-based diets that contained 0 (protein-free diet), 10, 30 or $40 \%$ CP from fish meal. Total chymotrypsin activity responded to an increase in dietary CP content. Dietary $\mathrm{CP}$ content had only a minor effect on total trypsin and amylase activities in pancreatic juice. However, the results from their study do not allow for comparison of total secretion of protein and enzyme activities between the four diets as these were fed in sequence $(0,30,10$ and $40 \% \mathrm{CP}$, respectively), therefore at different BW. As was reported previously (e.g., Gabert et al.,1996) BW may affect total enzyme activities in pancreatic juice.

The objective of this study was to determine the effect of dietary protein level on the exocrine pancreatic secretions of protein and enzyme activities in growing pigs prepared with the "Pouch" technique (Hee et al., 1985). Two maize starch-based diets containing 12 and $24 \%$ CP from soyabcan meal were evaluated. The range from 12 to $24 \% \mathrm{CP}$ was chosen as it encompasses the $\mathrm{CP}$ content of diets usually fed to pigs. The amino acid content in both diets met the NRC (1988) requirements.

\section{MATERIAL AND METHODS}

\section{Animals and diets}

Six PIC (Pig Improvement Canada) barrows (Camborough x Canabrid), average body weight $20.2 \pm 0.9 \mathrm{~kg}$, were obtained from the University of Alberta Swine Research Unit. The pigs were housed individually in stainless steel metabolism crates in a barn in which the temperature was maintained at $25 \pm 1^{\circ} \mathrm{C}$. The pigs were given ad libitum access to a grower dict containing $16 \%$ CP (Sauer et al., 1983). Water was freely available from as low-pressure drinking nipple.

After two days, the pigs were fitted with a pancreatic re-entrant cannula according to procedures adapted from Hee et al.(1985) with modifications described by Gabert et al. (1996). Procedures for pre-operative, surgery and post-operative care were previously described by Hee et al.(1985). The pigs were immediately returned to the metabolism crates after surgery and fasted that same day. The next day they were given approximately $100 \mathrm{~g}$ of a starter diet containing 18\% CP (Sauer et al., 1983) twice daily. The daily fecd allowance was gradually increased until the pigs consumed the diet at a rate of $5 \%(w t / w t)$ of 
TABLE 1

Formulation of the experimental diets, $\%$

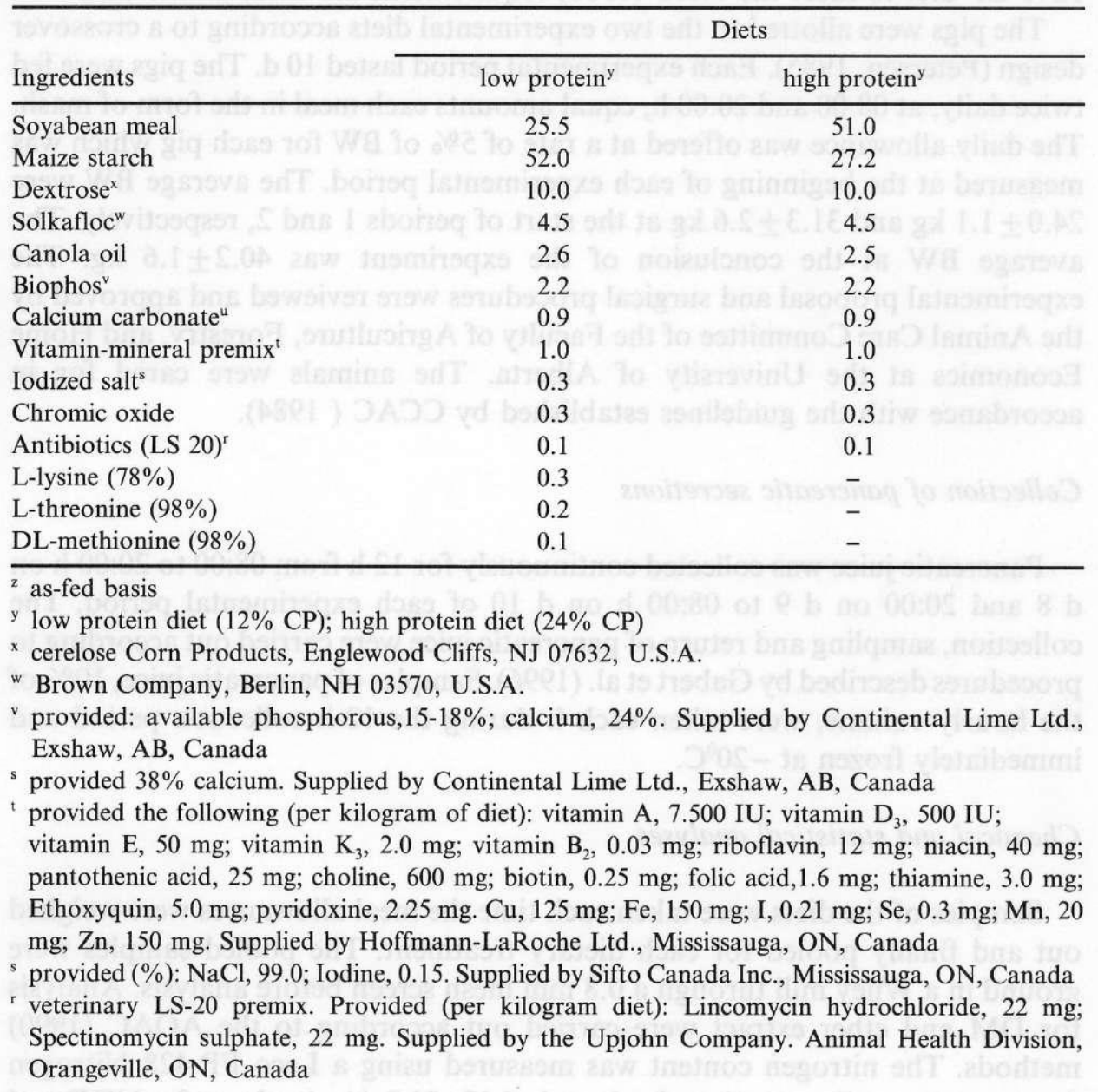

their individual BW. The re-entrant cannula and the connecting one-way valve were flushed with saline twice daily during the first three days after surgery to ensure that there was no blockage. The pigs were allowed a 14-d recuperation period during which time the starter diet was fed.

Two maize starch-based soyabean meal diets were formulated to contain 12 and $24 \%$ CP (Table 1). Soyabean meal $(47 \%$ CP) was ground through a $2-\mathrm{mm}$ mesh screen prior to incorporation into the diets. Solkafloc and canola oil were included in the diets. Dextrose $(10 \%)$ was included to possibly improve the palatability. Vitamins and minerals were supplemented according to the NRC 
(1988) requirements. Lysine, threonine and methionine were also included in the $12 \%$ CP diet to meet the NRC (1988) requirements for these amino acids.

The pigs werc allotted to the two experimental diets according to a crossover design (Petersen, 1985). Each experimental period lasted $10 \mathrm{~d}$. The pigs were fed twice daily, at 08:00 and 20:00 h, equal amounts each meal in the form of mash. The daily allowance was offered at a rate of $5 \%$ of $\mathrm{BW}$ for each pig which was measured at the beginning of each experimental period. The average BW were $24.0 \pm 1.1 \mathrm{~kg}$ and $31.3 \pm 2.6 \mathrm{~kg}$ at the start of periods 1 and 2 , respectively. The average $\mathrm{BW}$ at the conclusion of the experiment was $40.2 \pm 1.6 \mathrm{~kg}$. The experimental proposal and surgical procedures were reviewed and approved by the Animal Care Committee of the Faculty of Agriculture, Forestry, and Home Economics at the University of Alberta. The animals were cared for in accordance with the guidelines established by CCAC ( 1984).

\section{Collection of pancreatic secretions}

Pancreatic juice was collected continuously for $12 \mathrm{~h}$ from $08: 00$ to $20: 00 \mathrm{~h}$ on d 8 and 20:00 on d 9 to $08: 00 \mathrm{~h}$ on $\mathrm{d} 10$ of each experimental period. The collection, sampling and return of pancreatic juice were carried out according to procedures described by Gabert et al. (1996). Samples of pancreatic juice, $10 \%$ of the hourly volume, were taken each $\mathrm{h}$ during the 12 -h collection period and immediately frozen at $-20^{\circ} \mathrm{C}$.

\section{Chemical and statistical analyses}

Samples of the diets were taken each time the meal allowances were weighed out and finally pooled for each dietary treatment. The pooled samples were ground in a Wiley mill through a $0.8 \mathrm{~mm}$ mesh screen before analysis. Analysis for DM and ether extract were carried out according to the AOAC (1990) methods. The nitrogen content was measured using a Leco FP-428 Nitrogen Analyzer (Leco Corporation, St. Joseph, MO, U.S.A). Analyses for NDF and ADF were carried out according to procedures outlined by Goering and van Soest (1970). Gross energy content was determined with an AC-300 Leco Automatic Calorimeter (Leco Corporation, St. Joseph, MO, U.S.A). Amino acid contents of the diets were determined according to procedures previously described by Li et al. (1994). The chemical composition of the experimental diets are presented in Table 2.

For the determination of protein content and enzyme activities, the hourly samples of pancreatic juice were thawed at $4^{\circ} \mathrm{C}$ and pooled, taking $2 \%$ of each hourly sample, for each pig and each 12-h collection period. Total nitrogen in pancreatic juice was measured with a Leco FP-428 Nitrogen Analyzer. The 
Chemical composition of the experimental diets ${ }^{2}, \%$

\begin{tabular}{|c|c|c|}
\hline \multirow[b]{2}{*}{ Ingredients } & \multicolumn{2}{|c|}{ Diets } \\
\hline & low protein ${ }^{y}$ & high protein ${ }^{y}$ \\
\hline Dry matter & 90.9 & 91.3 \\
\hline Protein ( $\mathrm{N} \times 6.25)$ & 13.4 & 26.0 \\
\hline Gross cnergy. $\mathrm{MJ} \mathrm{kg}^{-1}$ & 16.3 & 16.7 \\
\hline Ether extract & 3.9 & 3.9 \\
\hline Neutral-detergent fïbre & 6.3 & 8.5 \\
\hline Acid-detcrgent fibre & 5.0 & 6.1 \\
\hline \multicolumn{3}{|l|}{ Amino acids: } \\
\hline \multicolumn{3}{|l|}{ Indipensable } \\
\hline arginine & 0.96 & 1.94 \\
\hline histidine & 0.34 & 0.70 \\
\hline isoleucine & 0.63 & 1.23 \\
\hline leucine & 1.03 & 1.98 \\
\hline lysine & 1.03 & 1.72 \\
\hline phenylanine & 0.67 & 1.34 \\
\hline threonine & 0.70 & 0.98 \\
\hline valine & 0.63 & 1.24 \\
\hline \multicolumn{3}{|l|}{ Dispensable } \\
\hline alanine & 0.57 & 1.11 \\
\hline asparatic acid & 1.41 & 2.74 \\
\hline glutamic acid & 2.34 & 4.57 \\
\hline glycine & 0.59 & 1.16 \\
\hline serine & 0.63 & 1.16 \\
\hline tyrosine & 0.33 & 0.73 \\
\hline
\end{tabular}

${ }^{\text {z dry matter basis }}$

${ }^{y}$ refer to Table 1

protein content in pancreatic juice was determined according to procedures described by Lowry et al. (1951). The standard curve was prepared using bovine serum albumin (Sigma Chemical Company, St. Louis, MO, U.S.A; Code: P-0914) as standard.

The activity of $\alpha$-amylase (EC 3.2.1.1) in pancreatic juice was determined according to procedures described by Rick and Stegbauer (1974) and the Enzyme Manual (WBC,1988); lipase (EC 3.1.1.1) activity according to Schmidt et al. (1974). Activities of trypsin and chymotrypsin in pancreatic juice were determined according to Rick (1974 a, b) following activation of chymotrypsinogen and trypsinogen to chymotrypsin and trypsin, respectively, by enterokinase (Sigma, enteropeptidase, EC 3.4.21.9; Code: E-0632). The activation procedures 
were carricd out according to Glazer and Steer (1977) with modifications described by Gabert et al. (1996).

Enzyme activities in pancreatic juice were expressed as units per litre $\left(U / 1^{-1}\right)$ for specific activities and units per $24 \mathrm{~h}\left(\mathrm{U} 24 \mathrm{~h}^{-1}\right)$ for total activities. One $\mathrm{U}$ of enzyme activity is defined as the amount of enzyme that hydrolyzes $1 \mu \mathrm{mol}$ of substrate in $1 \mathrm{~min}$ at $25^{\circ} \mathrm{C}$. Total enzyme activity was calculated as the product of specific activity and total volume of pancreatic juice secreted in $24 \mathrm{~h}$. Previous studies with pigs (Hee et al., 1988; Pöhland et al., 1993) showed no differences $(P>0.05)$ in secretion volume, protein content and enzyme activities of pancreatic juice collected between day (08:00 to 20:00 h) and night $(20: 00$ to $08: 00 \mathrm{~h})$ under conditions when pigs were fed twice daily $12 \mathrm{~h}$ apart, equal amounts each meal. Therefore, results obtained from each 12-h collection are representative of a $24-\mathrm{h}$ collection.

Results were subjected to analysis of variance using the General Linear Model procedure of SAS (1990). The statistical model included dietary treatments, experimental periods, animals and interactions between dietary treatments and experimental periods and animals as sources of variation. The means of dietary treatments and experimental periods were compared with the Students' t-test (Steel and Torrie, 1980).

\section{RESULTS AND DISCUSSION}

The pigs remained healthy and consumed their meal allowances in $30 \mathrm{~min}$ after feeding throughout the experiment. Postmortem examinations, conducted at the conclusion of the experiment, revealed no intestinal adhesions or other abnormalities.

The effect of dietary CP level on the volume of pancreatic juice is presented in Table 3 . The total volume of pancreatic secretion was slightly higher $(\mathrm{P}<0.05)$ when the low $(12 \% \mathrm{CP})$ compared with the high protein diet $(24 \% \mathrm{CP})$ was fed. This was likely caused by the lower buffering capacity of the low protein diet in the stomach, resulting in a higher $\mathrm{pH}$ in digesta in the duodenum and secretion of secretin, thereby increasing the flow of pancreatic juice. The volume of secretion of pancreatic juice in this study was lower than those reported by Hee et al. (1988) and Pöhland et al. (1993) in studies with larger pigs, but similar to those reported by Gabert et al.(1996) with pigs in the same BW range that were also fed maize starch-based soyabean meal diets.

The concentration of protein in pancreatic juice was higher $(\mathrm{P}<0.05)$ when the high protein diet was fed (Table 3$)$. There was no effect $(P>0.05)$ of dietary $\mathrm{CP}$ level on the daily secretion of protein. The daily protein output in pancreatic juice was approximately $10 \mathrm{~g}$, which accounted for only 6.0 and $3.4 \%$ of the 
TABLE 3

Volume of secretion, protein and enzyme activities in pancreatic juice from pigs fed the experimental diets

\begin{tabular}{|c|c|c|c|c|}
\hline \multirow[b]{2}{*}{ Items } & & \multicolumn{3}{|c|}{ Diets } \\
\hline & & low protein ${ }^{x}$ & high protein ${ }^{x}$ & $\mathrm{SE}^{\mathrm{y}}$ \\
\hline Volume & $\mathrm{mL} 24 \mathrm{~h}^{-1}$ & $2410.4^{a}$ & $2229.0^{\mathrm{b}}$ & 33.97 \\
\hline \multirow[t]{2}{*}{ Protein } & $\mathrm{g} \mathrm{L}^{-1}$ & $4.2^{b}$ & $4.8^{\mathrm{a}}$ & 0.13 \\
\hline & g $24 \mathrm{~h}^{-1}$ & 10.0 & 10.1 & 0.53 \\
\hline \multicolumn{5}{|l|}{ Enzyme activities: } \\
\hline \multirow[t]{2}{*}{ hymotrypsin } & $\mathrm{UL}^{-1} \times 10^{-3}$ & $44.8^{\mathrm{R}}$ & $55.9^{A}$ & 0.46 \\
\hline & U $24 \mathrm{~h}^{-1} \times 10^{-3}$ & 107.2 & 119.7 & 4.73 \\
\hline \multirow[t]{2}{*}{ trypsin } & $\left.\mathrm{L} \mathrm{L}^{-1} \times 10^{-3}\right)$ & 43.4 & 53.5 & 8.49 \\
\hline & $\mathrm{U} 24 \mathrm{~h}^{-1} \times 10^{-3}$ & 94.8 & 103.0 & 12.34 \\
\hline \multirow[t]{2}{*}{ amylase } & $U \mathbf{L}^{-1} \times 10^{-3}$ & $553.0^{\mathrm{B}}$ & $630.6^{\wedge}$ & 12.72 \\
\hline & $\mathrm{U} 24 \mathrm{~h}^{-1} \times 10^{-3}$ & 1276.0 & 1265.3 & 129.90 \\
\hline \multirow[t]{2}{*}{ lipase } & $\mathrm{U} \mathrm{L}^{-1} \times 10^{-3}$ & 44.2 & 44.4 & 1.35 \\
\hline & $\mathrm{U} 24 \mathrm{~h}^{-1} \times 10^{-3}$ & 105.2 & 93.8 & 3.04 \\
\hline
\end{tabular}

* refer to Table 1

${ }^{y}$ standard error of the mean $(n=12)$

${ }^{a}{ }^{\mathrm{b}} \mathrm{b}$ means in the same row with different superscript letters differ at $\mathrm{P}<0.05$

A, B means in the same row with different superscript letters differ at $\mathbf{P}<0.01$

dietary $\mathrm{CP}$ intake of pigs fed the low and high protein diets, respectively. From this study, it seems that the pancreatic protein output is not affected by the dietary $\mathrm{CP}$ content, in the range from 12 to $24 \%$. It should be pointed out that the amino acid supply in the low protein diet, which was supplemented with lysine, methionine and threonine, met NRC (1988) requirements. As was suggested by Imbeah et al. (1988), only very large differences in dietary CP content may perhaps elicit differences in pancreatic protein output.

The specific activity of chymotrypsin was higher $(P<0.01)$ when the high protein diet was fed (Table 3). However, its total activity was not affected $(\mathrm{P}>0.05)$ by dietary $\mathrm{CP}$ content. In addition, there was no effect $(\mathrm{P}>0.05)$ of dietary CP level on both specific and total activities of trypsin. Pöhland et al.(1993), in studies with pigs fed four diets ranging from 11.2 to $18.6 \% \mathrm{CP}$, also observed no effect $(P>0.05)$ of dietary $C P$ content on the total activities of chymotrypsin and trypsin. However, in these studies the dietary protein originated from different protein-containing feedstuffs. In addition, other dietary factors may have influenced pancreatic enzyme activities.

The specific activity of $\alpha$-amylase was higher $(\mathrm{P}<0.01)$ in pancreatic juice from pigs fed the high protein diet (Table 3). However, there was no effect $(P>0.05)$ of dietary CP content (or inversely of starch content) on the total activity of $x$-amylase. These results do not agree with those reported by Corring 
(1975) and O7imek et al. (1995) who observed that the pancreatic secretion of $\alpha$-amylase in pigs was very sensitive to changes in the dietary starch content. For example, studies by Ozimek et al. (1995) showed a $50 \%$ decrease in total $\alpha$-amylase secretion when $15 \%$ maize starch was replaced by $15 \%$ fat in a $15 \%$ CP maize starch-based soyabean meal diet.

As expected, there was also no effect $(P>0.05)$ of dietary $C P$ level on the activities of lipase (Table 3); the ether extract content was similar in both diets (Table 2). As was reported by Corring (1977) unless there is a substantial change in the dietary ether extract content, there is no effect on lipase activity.

The present study showed that there was no effect $(P>0.05)$ of dietary $\mathrm{CP}$ level, from 12 to $24 \%$, on the total secretion of protein and enzyme activities in pancreatic juice. Hee et al. (1988) fed pigs maize starch-based diet that contained $15 \%$ protein from soyabean meal or a maize starch-based $15 \%$ protein-free diet. There were no differences $(\mathrm{P}>0.05)$ in the total secretion of protein in pancreatic juice and lipase activity. However, the total activities of trypsin, chymotrypsin and amylase in pancreatic juice were considerably lower $(\mathrm{P}<0.05)$ in pigs fed the protein-free diet, likely as a result of the protein-deficient status that was induced.

The effect of experimental period on the total volume, protein content and enzyme activities of pancreatic juice are presented in Table 4 . The average BW of the pigs were 27.6 and $35.8 \mathrm{~kg}$ during experimental periods 1 and 2 , respectively (average BW from the start to the end of each experimental period). The total volume of secretion of pancreatic juice and protein were higher $(\mathbf{P}<0.01)$ in period 2 than 1 . With respect to the enzymes, the specific activities of all enzymes, with the exception of trypsin, were lower $(\mathrm{P}<0.01)$ in period 2. The total activities of these enzymes were higher in period 2 than 1 . The differences were significant $(\mathbf{P}<0.01)$ for chymotrypsin and lipase. These results are in general agreement with previous studies ( $\mathrm{Li}$ et al.,1996) in which the volume of pancreatic secretion and total protein secretion were higher $(\mathrm{P}<0.05)$ during the second experimental period. Furthermore, the total activities of $x$-amylase and chymoirypsin were also higher in period 2 than 1 although not significant. These results confirm the findings of Weström et al. (1988), as BW increases secretion rate increases. Gabert et al. (1996) also reported an increase in the secretion volume, protein output and activities of some of the pancreatic enzymes with increasing BW.

Protein in pancreatic juice is one of the endogenous protein sources secreted into the digestive tract. This study shows that the secretion of total pancreatic protein is not affected by dietary $\mathrm{CP}$ content, over the range from 12 to $24 \%$. A recent study by Fan et al. (1995), with growing pigs using the regression method, showed that the level of endogenous protein (amino acids) collccted from the distal ileum was constant at different dietary CP levels. Results from 
TABLE 4

Effect of expcrimental period on volume of secretion, protein and enzyme activities in pancreatic juice from pigs

\begin{tabular}{|c|c|c|c|c|}
\hline Items & & Period 1 & Period 2 & $\mathrm{Se}^{z}$ \\
\hline Volume & $\mathrm{ml} 24 \mathrm{~h}^{-\mathrm{i}}$ & $1761.8^{\mathrm{B}}$ & $2877.7^{\mathrm{A}}$ & 33.97 \\
\hline \multirow[t]{2}{*}{ Protein } & $\mathbf{g} \mathbf{L}^{-1}$ & 4.6 & 4.4 & 0.13 \\
\hline & $\mathrm{g} 24 \mathrm{~h}^{-1}$ & $7.6^{\mathrm{B}}$ & $12.4^{\mathrm{A}}$ & 0.53 \\
\hline \multicolumn{5}{|l|}{ Enzyme activities: } \\
\hline \multirow[t]{2}{*}{ hymotrypsin } & $\mathrm{U} \mathrm{L} \mathrm{h}^{-1} \times 10^{-3}$ & $52.2^{\mathrm{A}}$ & $48.5^{\mathrm{B}}$ & 0.46 \\
\hline & $\mathrm{U} 24 \mathrm{~h}^{-1} \times 10^{-3}$ & $88.9^{\mathrm{B}}$ & $138.1^{\mathrm{A}}$ & 4.73 \\
\hline \multirow[t]{2}{*}{ trypsin } & U I. $h^{-1} \times 10^{-3}$ & 60.9 & 36.0 & 8.49 \\
\hline & U $24 \mathrm{~h}^{-1} \times 10^{-3}$ & 97.4 & 100.3 & 12.34 \\
\hline \multirow[t]{2}{*}{ amylase } & $\mathbf{U} \mathbf{L} \mathbf{h}^{-1} \times 10^{-3}$ & $665.7^{\mathrm{A}}$ & $517.9^{\mathrm{B}}$ & 12,72 \\
\hline & $\mathrm{U} 24 \mathrm{~h}^{-1} \times 10^{-3}$ & 1091.0 & 1450.3 & 129.93 \\
\hline \multirow[t]{2}{*}{ lipase } & $\mathbf{U} \mathbf{L ~ h}^{-1} \times 10^{-3}$ & $48.6^{\mathrm{A}}$ & $39.9^{\mathrm{B}}$ & 1.35 \\
\hline & C $24 \mathrm{~h}^{-1} \times 10^{-3}$ & $84.2^{B}$ & $114.7^{\mathrm{A}}$ & 3.04 \\
\hline
\end{tabular}

${ }^{z}$ standard error of the mean $(\mathbf{n}=12)$

${ }^{A}{ }^{B}$ means in the same row with different superscript letters differ at $\mathbf{P}<0.01$

this study, as far as pancreatic protein secretion is concerned, support the findings by Fan et al. (1995). However, it should be pointed out that the pancreatic protein secretion is only a partial measurement of endogenous protein in ileal digesta; other sources which include sloughed epithelial cells, mucus and intestinal secretions should also be considered.

In conclusion, dietary $\mathrm{CP}$ levels ranging from 12 to $24 \%$ did nol affect the total secretion of protein and total enzyme activities in pancreatic juice. An increase in BW augmented the volume of pancreatic secretion, total protein and enzyme activities.

\section{ACKNOWLEDGEMENTS}

Financial support provided by the Natural Sciences and Engineering Research Council of Canada is gratefully acknowledged. The authors also thank Brenda Tchir and Charlane Gorsack for o their assistance with surgery. 


\section{REFERENCES}

AOAC, 1990. Official Methods of Analysis of the Association of Official Analytical Chemists. 15th cdition, Arlington, VA, USA

CCAC, 1984. Guide to the Care and Use of Experimental Animals. Vol. 1 (with addendum). Canadian Council on Animal Care, Ottawa, ON, Canada

Corring T., 1977. Possible role of hydrolysis products of the dietary components in the mechanisms of the exocrine pancreatic adaptation to the diet. Wld. Rev. Nutr. Diet. 27, 132-144

Corring T, , 1975. Adaptation de la sćcretion du pancréas exocrine au régimc alimentaire chez le porc. Physiologie comparée, étude expérimentale et mécanismes. Thesis Doct. Etat Sci. Nat., Paris, France

Corring T. Saucier R., 1972. Secretion pancreatique sur pore fistule. Adaptation a la teneur en proteines du régime. Ann. Biol. anim. Bioch. Biophys. 12, 223-241

Fan M.7., Sauer W.C., McBurney M.I., 1995. Fstimation by regression analysis of endogenous amino acid levels in digesta collected from the distal ileum of pigs. J. Anim. Sci. 73, 2319-2328

Gabert V.M., Sauer W.C., Li S., Fan M.Z., Rademacher M.,1996. Exocrine pancreatic secretions in young pigs fed diets containing faba beans (Vicia faba) and peas (Pisum sativum): Nitrogen, protcin and enzyme secretions. J. Sci. Food Agric. 70, 247-255

Glazer G., Steer M.L.,1977. Requirements for activation of trypsinogen and chymotrypsinogen in rabbit pancreatic juice. Anal. Biochem. 77, 130-140

Goering H.K., van Soest P.J., 1970. Forage Fibre Analysis. USDA Agriculture Handbook, 379. Washington, DC

Hee J., Sauer W.C., Mosenthin R., 1988. The measurement of pancreatic secretions in the pig with the pouch technique. J. Anim. Physiol. Anim. Nutr. 60, 241-248

Hee J., Sauer W.C., Berzins R. Orimek L., 1985. Permanent re-entrant diversion of pancreatic secretions. Can. J. Anim. Sci. 65, 451-457

Imbeah M., Sauer W.C., Mosenthin R., 1988. The prediction of the digestible amino acid supply in barley-soybean meal or canola meal diets and pancreatic enzyme secretion in pigs. J. Anim. Sci. $66,1409-1417$

Li S., Sauer W.C., Huang S.X., Hardin R.T., 1996. Response of pancreatic secretions to feeding diets of high and low levels of soybean trypsin inhibitors in growing pigs. J. Sci. Food Agric. (accepted)

Li S., Sauer W.C., Hardin R.T., 1994. Effect of dietary fibre level on amino acid digestibility in young pigs. Can. J. Anim. Sci. 74, 327-333

Lowry O.H., Rosebrough N.J., Farr A.L., Randall R.J.,1951. Protein measurement with the Folin phenol reagent. J. Biol. Chem. 93, 265-275

NRC, 1988. Nutrient Requirements of Swine. 9th Edition, National Academy Press, Washington, DC, USA

Ozimek L., Mosenthin R., Sauer W.C., 1995. Effect of dietary canola oil and its degree of oxidation on exocrine pancreatic secretions in growing pigs. Z. Ernährungswiss. 34, 224-230

Petersen R.G., 1985. Design and Analysis of Experiments. 2nd ed. Marcel Dekker Inc. New York and Basel, pp. 305-306

Pöhland U., Souffrant W.B., Sauer W.C., Mosenthin R., de Lange C.F.M., 1993. Effect of feeding different diets on the exocrine pancreatic secretion of nitrogen, amino acids and enzymes in growing pigs. J. Sci. Food Agric. 62, 229-234

Rick W., 1974a. Trypsin: Measurement with $\mathrm{N}_{\alpha}$-p-toluenesulphonyl-arginine methyl ester as substrate. In: H. U. Bergmeyer (Editor). Methods of enzymatic analysis. Vol. 2. Verlag Chemie Weinheim, Academic Press Inc., New York, pp. 1021-1024

Rick W., 1974b. Chymotrypsin: Measurement with N-benzoyl-L-tyrosine ethyl ester as substrate. In: 
H.U. Bergmeyer (Editor). Methods of enzymatic analysis, Vol. 2. Verlag Chemie Weinheim, Academic Press Inc., New York, pp. 1009-1012

Rick W., Stegbauer, H.P., 1974. $x$-amylase measurement of reducing groups. In: H. U. Bergmeyer (Editor). Methods of enzymatic analysis, Vol. 2. Verlag Chemie Weinheim, Academic Press Inc., New York, pp. 885-890

SAS,1990. SAS/STAT user's guide (Rclcasc 6.03). SAS institute Inc., Cary, NC, USA

Sauer W.C., Jörgensen H., Berzins R., 1983. A modificd nylon bag technique for determining apparent digestibilities of protein in feedstuffs for pigs. Can. J. Anim. Sci. 63, 233-237

Schmidt F.H., Stork H., von Dahl K., 1974. Lipase: photometric assay. In: H. U. Bergmeyer (Editor). Methods of enzymatic analysis, Vol. 2. Verlag Chemie Weinheim, Academic Press Inc., New York, pp. 819-823

Steel R.G.D., Torrie J.H., 1980. Principles and Procedures of Statistics: A Biometrical Approach. 2nd ed. McGraw-Hill Book Publishing Co., New York, NY

WBC, 1988. Worthington Enzyme Manual. In: C.C. Worthington (Editor). Worthington Biochemical Corporation, Freehold, NJ

Weström B.R., Pierzynowski S.G., Karlsson B.W., Svendsen J., 1988. Development of the exocrine pancreatic function: response to food and hormonal stimulation in pigs from birth up to after 12 weaning. In: I. Buraczewska, S. Buraczewski, B. Pastuszewska, T. Żebrowska (Editors). Digestive physiology in the pig. Institute of Animal Physiology and Nutrition, Polish Academy of Sciences, Jablonna (Poland), pp. 36-43

\section{STRESZCZENIE}

Sekrecja soku trzustkowego u rosnących świń żywionych dawkami zawierającymi różnq̨ ilość bialka śruty sojowej

S7eść wieprzków o początkowej masie ciała $20,2 \pm 0,9 \mathrm{~kg} \mathrm{z}$ mostkową kaniulą przewodu trzustkowego żywiono dwa razy dziennie, w układzie przemiennym, śrutą kukurydzianą uzupełnioną śrutą sojową do poziomu 12 lub $24 \%$ białka ogólnego w dawce. Średnia masa ciała na początku okrcsów 1 i 2 wynosiła odpowiednio $24,0 \pm 1,0$ i $31,3 \pm 2,6 \mathrm{~kg}$, a przy zakończeniu doświadczenia $40,2 \pm 1,6 \mathrm{~kg}$. Objçtość wydziclanego w ciągu doby soku była większa $(\mathrm{P} \leqslant 0,05)$ u świń otrzymujących dietę o niższym poziomie białka. Nie stwierdzono różnic $(P \geqslant 0,05)$ w ilości białka wydzielanego w ciągu doby w soku trzustkowym, chociaż stężenie białka $(\mathrm{g} / 1)$ było większe $(\mathrm{P} \leqslant 0,05) \mathrm{u}$ świń żywionych dictą o większej zawartości białka. Poziom białka $w$ diecie nie miał wpływu $(P \geqslant 0,05)$ na całkowitą aktywność (jednostek/dobę) chymotrypsyny, trypsyny, amylazy i lipazy, natomiast specyficzná akiywność (jednostki/1) chymotrypsyny i amylazy była większa $(P \leqslant 0,05)$ przy skarmiania dawki o większej zawartości bialka. Objętość wydzielanego soku trzustkowego, ilość wydzielanego w soku białka oraz aktywność chymotrypsyny i lipazy zwiększały siç $(P \leqslant 0,05)$ wraz ze wrrostem masy ciała zwier/ąl.

Wnioskuje się, że poziom białka w diecie w granicach od 12 do $24 \%$ nie wplynął na ilość wydzielanego w soku trzustkowym w ciągu doby białka ani na ilość wydzielanych jednostek aktywności enzymów. 